Nambukara-Gamage \& Rahman, 2020

Volume 6 Issue 1, pp. 331-348

Date of Publication: $11^{\text {th }}$ April 2020

DOI-https://doi.org/10.20319/pijss.2020.61.331348

This paper can be cited as: Nambukara-Gamage, B., E Rahman, S. (2020). Ethics in Accounting Practices and its Influence on Business Performance. PEOPLE: International Journal of Social Sciences, 6(1), 331348.

This work is licensed under the Creative Commons Attribution-Non Commercial 4.0 International License. To view a copy of this license, visit http://creativecommons.org/licenses/by-nc/4.0/ or send a letter to Creative Commons, PO Box 1866, Mountain View, CA 94042, USA.

\title{
ETHICS IN ACCOUNTING PRACTICES AND ITS INFLUENCE ON BUSINESS PERFORMANCE
}

\author{
Bandula Nambukara-Gamage \\ Charles Stuart University, Study Group Australia, Brisbane, Australia \\ bnambukara-gamage@studygroup.com
}

Samena Rahman

Central Queensland University, Brisbane Campus, Australia samena_r@yahoo.com

\begin{abstract}
The objective of this study is to investigate and identify the importance of ethics in accounting practices and whether ethical accounting practices has any influence on the overall business performance and to create a guideline to encourage accounting professionals to understand and adopt ethical practices. The study explores how various demographical variables, specifically focusing on culture, gender and religion influence on an individual's ethical decision-making process. The data used in this study was collected from the relevant literatures. The portals' filters were used to identify the relevant literature to the research. The sample was chosen based upon the four themes including influence of ethical accounting practices on culture, gender, religion and impact on overall business performance. This study revealed that culture does not necessarily influence on ethical behaviour and decision-making. Conversely, a positive correlation has been found between the religion beliefs and ethical decision-making process. However, this research does not clearly point out the influence of ethical accounting practices and its influence on the business performance. This research also highlighted partial connections between how unethical accounting practices and fraudulent activities can become a threat to the business existence. The sample size and research technique restrict the results from generalising.
\end{abstract}




\section{Keywords}

Ethics, Business Performance, Accounting Practices, Decision-Making Process

\section{Introduction}

Ethical standards and principals are crucial for any profession that intends to advance their professional aptitudes and develops overall business efficiencies. In fact, accounting is a profession that comprehensively depends on the professional's judgement and their principals which includes objectivity, independence, confidentiality, competency, integrity, professional behaviour and due care (Park \& Blenkinsopp, 2013). Then, by performing different functions, such as, recording all business events with financial character, classifying and summering them, recording and presenting them in the form of profit and loss statement, balance sheet and cash flow statement accounting helps businesses to track their financial events (Holmes, Marriott \& Randal, 2012). All these activities are very critical to perform and requires ethical standards to be maintained throughout the process, thus accountants are consider as the front runner in business while it comes to upholding a quality financial report and provide the interests groups with reliable financial information (Ismail, 2014).

However, there were number of events had been transpired which has questioned the integrity of the profession and lighten the reputation it usually poses. For example, accounting professionals were involved in breaching accounting principles and standards; manipulating financial information; failed to display professionalism, independence and due care; engaged in creative accounting and tax fraud; and other fraudulent activities (Jackling, Cooper, Leung \& Dellaportas, 2007). In such circumstances, it is crucial to restore the public trust in the accounting profession and to ensure that ethical practices and values need to be exercise by accountants while carrying out their roles and avoid actions that might consider as unethical (Bonawitz, 2002). The research purpose is to identify how ethical principles are central to accounting practices and whether it has any influence on overall business performance. This report will begin with by outlining the problem statement and research objectives. Following that, it will constructively present a literature review to support the research purpose and describe the methodologies that have been carried out to execute the research. Finally, the research findings and results will be discussed, and recommendations will be provided for further study.

\subsection{Problem Identification and Objectives}

Ethics is defined as the "fundamental concept of right human conduct, which involves differentiating between good and bad, right and wrong" (Abuznaid, 2009, p.279). Ethics is considered as the primary requirement in accounting due to its radical contribution to the 
economic growth and public interests (Mohamed Saat, Porter \& Woodbine, 2012). Besides, Joseph (2010) characterised the ethical accounting practices by honesty, integrity, fairness and equity in interpersonal, professional and academic relationship. In fact, McMurrian and Matulich (cited in Ibidunni, Okere, Ibidunni, \& Joshua, (2018) stated that accounting ethics contributes to profitability by reducing the cost of business transactions, building a foundation of trust with stakeholders, contributing to an internal environment of successful teamwork and maintaining social capital that is part of an organisation's market-place image. Thus, accountants should not engage in activities which involves manipulation of financial figures or break the professional code of conducts under any circumstances.

Additionally, professional accountants contribute to achieve overall business strategy by helping to prepare budgets, providing financial advice, reducing costs, assisting top management, providing tax advice and by helping to alleviate risks (Hooper \& $\mathrm{Xu}, 2012$ ). In contrast, accountants frequently face conflicting situations between upholding their client's demands and maintaining their ethical values and integrity to the profession. For instance, client might pressure accountants to record inventories at highest values or select alternative accounting methods which present a favourable financial picture of the corporations' health (Chartier cited in Adkins \& Radtke, 2004).

Therefore, considering the circumstances, it is crucial to analyse and understand why ethical practices play such an important role in the field of accounting and weather adopting ethical accounting practices has any influence on overall business performance. This exploratory research study will contribute to the current accounting field and will help to identify gaps in previous research studies with empirical evidence and the losses/failures suffered by accounting professionals/organisations due to underestimating the importance of ethics while performing their accounting practices. Besides, the influence of culture, gender, religion and the ethical code and principals on ethical accounting practices will also be taking under consideration to justify their validity and effectiveness. This research study is exclusively based on secondary data resources, and information analysed and collected from these resources will be beneficial to existing and future accounting professionals/policy makers. The principal objectives of the study were as follows:

- Why ethical practices play such an important role in the accounting field?

- Is ethical values and principals influenced by culture, gender and religion believes?

- Is there any connection between ethical accounting practices \& business performance?

- What ethical issues/ barriers accounting professionals face to carry out their duties? 
These objectives will help to execute the most important aim of this study by outlining a clear knowledge on why accountants need to be ethical while performing their duties and how things can turn around in the absence of ethics in accounting professionals.

\section{Literature Review}

Accounting is "the process of identifying, measuring and communicating economic information to permit judgements and decision-making by users of the information" (Adeniji cited in Enofe, Nakpodia \& Moruku, 2014, p.144). It is known as the language of business that allows the passing of information and it is undoubted that the well-functioning of an economy immensely depends on accurate and reliable accounting information (Costuleanu, Dumitre \& Bobiţan, 2013). However, the accounting profession is experiencing its deepest crisis over the last two decade after the exposure of several accounting scandals that lead towards the collapse of some big corporations. For instance, Waste Management in 1998; Enron in 2001; WorldCom and Tyko in 2002; HealthSouth and Freddie Mac in 2003; AIG in 2005; Madoff and Lehman Brothers in 2008 and Saytam in 2009 (Busila, 2014). The key reason behind all these scandals involved unethical accounting practices, fraudulent financial reporting and misappropriation of assets and expenses (Ritholtz cited in Busila, 2014). Indeed, a survey conducted by the international accounting firm KPMG reported that there is approximately $13 \%$ increase in the corporate fraudulent activities compare to five year earlier (Rahaman \& Hossain, 2014). These high-profile scandals and embarrassing corporation failure have called to question the integrity of the accounting professionals and leading to increased demands for ethics.

Ethics in accounting is one of the most important, yet most misunderstood concerns in the world of business. According to Stonciuviene and Naujokaitiene (2013) insufficient and inappropriate understanding of the ethical norms and wrong interpretation direct accountants towards the unethical behaviour. In Support, Busila (2014) indicated that simply awareness of the professional ethical standards and code of professional conduct does not guarantee that an accountant will behave ethically. Therefore, it is necessary to understand the ethical decisionmaking process as significant proportion of professional judgement depends on the individual's ethical beliefs and attitudes (Richmond, 2001). An individual's ethical decision-making depends on number of demographic factors, such as culture, gender, religion, age, education, value system, moral character and sensitivity to moral issues (Hunt \& Vitell cited in Enofe, Nakpodia \& Moruku, 2014). This literature review aims to present a critical overview of the extent to which culture, gender and religion impact on individual's ethical decision-making along with influence of ethical accounting practices on business performance. 


\subsection{Influence of Culture on Ethical Accounting Practices}

Each nation has a culture that is made up of their unique traditions, history, ideas and values which significantly influences their behaviours, characteristics, habits, customs, ethical norms and beliefs. Thus, people from diverse cultural background response differently to a certain situation due to their cultural differences (Roxas \& Stoneback, 2004). Then, number of empirical studies have showed that culture is consider as an important environmental factor that influences a country's accounting system (Gray; Davidson; Doupnik; Salter \& Niswander; \& Zarzeski cited in Abongwa, 2006). Certainly, failure to consider the cultural differences will likely deter the acceptance of any established international accounting practices and standards (Abongwa, 2006). Further, several cross-cultural studies found that cultural differences can extensively impact on ethical decision-making in the accounting industry ( $\mathrm{Li}$ and Persons; Su, Kan and Yang; Ho; Ho and Lin cited in Anderson, 2014). For example, a study conducted by Mirshekary and Lawrence (2009) based upon Hofstede's cultural dimensions (Individualism/Collectivism, Masculinity/Femineity, Power distance and Uncertainty avoidance) found that individuals within a high uncertainty avoidance culture are more likely to cheat compare to low uncertainty avoidance culture. Thus, culture forms the foundations for an individual's ethical behaviour and determines what is ethical and what is consider as unethical (Venezia, 2004).

\subsection{Influence of Gender on Ethical Accounting Practices}

Gender differences in ethical decision-making has become a topic of great interest as more women are entering the workforce and making remarkable contribution into the management, accounting and leadership roles (Roxas \& Stoneback, 2004). According to Persons (cited in Holmes, et al., 2012) observation, male and female distinctively pose different values and traits, thus creating different moral orientations that results in different decisions and practices. Females are more concerned with maintaining harmonious relationship and performing well which prevent them from engaging in unethical behaviours; where males are more concerned with money and advancement and tend to involve in unethical activities (Anderson, 2014). Then, numerous studies with different scenarios and research techniques has revealed that females tend to have higher levels of ethical behaviours compare to males (Barnett \& Brown; Borkowski \& Ugras; Burton et al.; Grasso \& Kaplan; Persons; Shaub; Thorne cited in Holmes et al., 2012). Similarly, O'Leary and Radich (2001) found that males are four times more likely to act unethically compare to females based upon their survey-based research. However, some research contradicts with the above findings and concluded that gender is not a significant determinant of differences in apparent moral intensity and ethical decision-making (Rest; Gilligan cited in Richmond, 2001). Further, Kitchen (2006) affirmed that majority of the research was conducted by using surveys, 
interviews and questionnaires at a point in time where women were a minority in the workforce. Thus, further research needs to be taken place with larger sample size to clarify the fact.

\subsection{Influence of Religion on Ethical Accounting Practices}

Religion beliefs are another key factor in ethical decision-making as personal values and standards are often related to an individual's religion background (Graafland, Kaptein \& Schouten cited in Ho, 2009). Then, O'Fallon and Butterfield (cited in Stichter, 2012) indicated that there is a positive relationship between religion and ethical decision-making. In fact, a study conducted by Jones, Furnham and Deile (2010) with a sample of 381 graduate and undergraduate students in the United States and the United Kingdom, aged between 19 to 50+ found a positive correlation between high work ethics and religion beliefs. Likewise, Ho (2009) found significant connection between religious beliefs with ethical reasoning ability after undertaking a study in Taiwan by involving accounting students. Further, Longenecker, McKinney and Moore (2004) surveyed 1,234 business professionals and found a major correlation between religion commitment and ethical judgement. Consequently, it is necessary for managers and other employees to understand how people with distinct religious beliefs have different perceptions of ethical issues in the workplace (Ho, 2009).

\subsection{Ethical Accounting Practices and Business Performance}

Understanding and upholding business ethics is essential for the overall business activities. According to $\mathrm{Su}$ (2014), an organisations stability and survival vastly depends on the consistency and quality of ethical financial decisions made by accountants. In fact, studies have shown that businesses with higher ethical commitment are engaged in less earning management, have higher market valuation and are supposed to have higher corporate financial performance (Ghazali, 2015). Indeed, a study conducted by Saeidi et al. (cited in Ibidunni et al., 2018) found the contribution of ethics in the performance of business. Ethical practices not only bring profitability but also increase customers loyalty, helps in retaining customers, create goodwill for the organisation and utilize the resources at the maximum level. In contrast, unethical accounting practices such as manipulating accounting figures to display higher profits, not recording expenses into appropriate time period, recording inventories at higher values and falsification of lease assets can not only misrepresent organisational financial status but can also become a threat to its existence (Buell, 2009). For example, WorldCom Chief Executive Officer and Chief Financial Officer was sentenced in prison for directing an $\$ 11$ billion accounting fraud which has drove the telecommunication giant into the nation's largest bankruptcy (Johnson; Krehm cited in Kitchen, 2006). Thus, in the case of professional accountants in business, not only they have to maintain high ethical standards but also, they need to play a key role in helping businesses to act ethically. 


\section{Methodology}

The purpose of this research study is to explore the importance of ethics in accounting practices and to identify whether ethical accounting practices has any influence on overall business performance. This study is designed on the bases of secondary data which is basically information collected with the original intention of answering to another purpose (Jacobsen cited in Isidorsson, 2010). Considering the research purpose, a qualitative research approach was deemed as an appropriate way to effectively and efficiently combine elements of data collection, analysis and reporting to ensure the skilful interpretation of the results (Kitchen, 2006). The qualitative method will provide a deep understanding of the importance of ethical accounting practices and identifies a common phenomenon (Leedy \& Ormrod cited in Sapp, 2015). The data used in this study was collected from various publications, databases and websites including Google, Proquest, Science Direct, Springer, Emerald, Academic Search Complete and Google Scholar which was accessed through CQU library site. The portals' filters were used to sort out and identify the relevant literature to the research context. The data was sort out by using the characteristics outlined in Table-1:

Table 1: Characteristics Used to Identify Suitable Data

\begin{tabular}{|l|l|}
\hline Characteristic 1: & They were ranged from 1990 to 2017 \\
\hline Characteristic 2: & They were within the field of accounting and business \\
\hline Characteristic 3: & They were academic data \\
\hline Characteristic 4: & They were related to ethics, accounting practices, business performance \\
\hline
\end{tabular}

By using the above filters, a total of 70 literatures were identified which was suitable for the research purpose, thus they were downloaded from the sites. Then, through a careful scanning of the 70 literatures, 22 papers were eliminated from further analysis due to insufficiency of information about the research topic. Through reading and understanding the remaining data, a sample of 16 research papers was chosen for the qualitative, in-depth analysis. The sample was chosen based upon four themes including influence of ethical accounting practices on culture, gender, religion and impact on business performance.

\section{Findings and Analysis}

This section of the report will present the project findings and analysis structured according to the themes outlined in the literature review. In order to provide a better understanding of the analysed data, a summary of the findings is displayed in Appendix-A. 


\subsection{Influence of Culture, Gender and Religion on Ethical Accounting Practices}

Through analysing all 16 of the research papers it has been identified that 8 papers comprehensively related to culture, 7 to gender and 3 papers relevant to the religion influence. The relationship between culture and ethical decision-making has been identified as significant in majority cases which is described in Journal-10 "differences in the value systems and ethical beliefs of people from different culture", except Journal-2 and 4, which has not found any substantial results on the influence of culture on ethical decision-making. In terms of gender influence, females have been recognized to act more ethically and question unethical practices compare to male as illustrated "gender influence responses ... female were found to indicate higher levels of unacceptability of unethical practices in business settings than males" (Journal-5). Conversely, 2 of the papers (Journal-2 and 4) have not found any major differences between gender ethical decision-making through their research. In fact, there are contradict results has been established "Chinese males had actually showed females are less likely to behave ethically" (Journal-2). While it comes to religion beliefs, 2 out of 3 papers (Journal-9 and 10) has showed significant connections between ethical reasoning and religion beliefs, while contradict results appears in Journal-11, which illustrated that "feeling of accountability to a group is motivating factor for ethical behaviour than religion beliefs".

\subsection{Influence of Ethical Practices on Business Performance}

While in terms of influence of ethical practices on business performance, 5 out of 16 papers were identified that has either completely or partly addressed this research theme. There are no significant results have been acknowledged that will establish a strong relationship between ethical practices and business performance. However, there are certain level of connections has been recognized which is illustrated in Journal-13 "collapse of Big 5 accounting firms . . . with the loss of 85,000 jobs worldwide and the loss of public trust".

\subsection{Summary of Findings}

In summary, the analysis of the selected sample has shown some significant results in the field of accounting and ethical practices and different demographic factors including culture, gender and religion belief influence on individuals' ability to distinguish between ethical and unethical acts. An inclusive analysis of the findings of this study will be discussed in the following section with the support of literatures. 


\section{Discussion}

This section will discuss the main findings of this project by comparing them to the literatures that has been addressed in section 2 above, and by comparing the similarities and differences between the project's findings and the literature.

\subsection{Influence of Culture on Ethical Accounting Practices}

The research data clearly points towards the influence of cultural values and beliefs on an individuals' ethical decision making and moral reasoning ability as 6 of 8 papers has found significant relationships between them. This research findings are also in line with authors like Anderson (2014) and Venezia (2004) who have clarified that cultural differences can extensively impact on ethical decision-making and distinguish between ethical and unethical acts. In fact, this finding confirms Abongwa's (2006) claim that culture is a major source of influence on accounting standards and practices. However, the data also outlined that culture does not necessarily always influence on ethical behaviour and decision-making and suggested that code of ethics and ethical education and programmes also has strong influence on ethical behaviour (Ghazali, 2015). This indicates that even though an individual belongs to a specific cultural background, through ethical education and training one can develop strong ethical values and characteristics and act ethically regardless of the cultural norms.

\subsection{Influence of Gender on Ethical Accounting Practices}

This finding suggests that gender differences is a crucial factor to determine the propensity of ethical decision-making among accounting professionals as 5 out of 7 papers confirms that females tend to act more ethically compare to males. The finding is also aligned with Persons (2009) observations which indicated that male and females pose different values and traits that direct towards different decisions and practices. In comparison, finding of this project partially confirms with the prior literature authors like Richmond (2001) and Kitchen (2006) who suggested that there is no significant difference exists between males and females' ethical behaviours. This study however, also found that, majority of the research conducted on gender does not had an equal sample size of male and female participants. The reason behind this is that female represented minor proportion of the workforce compare to males when these studies were conducted and their presence in accounting profession were very constricted, which restricts the results.

\subsection{Influence of Religion on Ethical Accounting Practices}

The research data found positive relation between the religion beliefs and ethical decisionmaking process as 2 of 3 papers had found significant relations between them. The findings of this study are also aligned with Stichter (2012) and Ho (2009), where they have claimed that there is a 
positive relationship between religion and ethical decision-making and individuals' personal values often related to it. In comparison, the research data also identified that religion does not motivate individuals' behaviours to act ethically rather accountability to the Code of Professional Conduct and concern for reputation among peers and family is an influential factor which is also claimed by Busila (2014). This may mean that individuals' preferences and social image might influence their ethical decision-making to be either act ethically or unethically.

\subsection{Influence of Ethical Accounting Practices on Business Performance}

The finding of this project does not clearly point out the influence of ethical accounting practices and its influence on the overall business performance. In comparison to the literature, prior research conducted by authors likes Su (2014), Ghazali (2015) and Buell (2009) found significant connection between ethical practices and business performance and claimed that organisations stability and survival depends on the quality of ethical decisions made by accountants. However, the data has found some partial connections which indicates that unethical accounting practices and fraudulent activities can become a threat to the business existence which confirmed by Kitchen (2006) and Ibidunni, et al. (2018). This indicates that if organisational economic performance misrepresents through unethical accounting practices, businesses not only violate the ethical rules but also threatening their future growth and business opportunities.

\subsection{Implications and Limitations of the Study}

Analysis for ethical/unethical behaviour is difficult and challenging to measure as there are limited numbers of research tools available with the capacity to achieve it (Holmes et al., 2012). Therefore, the finding of this research might not be significant due to limitations of sample size and the data collection method. Regardless of that the study can be beneficial to get an overview of the importance of ethical practices in the field of accounting and how cultural, gender and religion factor influence on individuals' ethical behaviours.

\section{Conclusion}

Ethics holds an essential role in accounting in order to ensure efficiency, integrity, accuracy, confidentiality and presentation of accurate financial information for any corporation. There are number of factors that directly and indirectly influence ethical decision-making such as culture, gender, religion beliefs, moral reasoning and ethical codes and principals. However, the significance of these variables on ethical decision-makings differs under certain circumstances. Culture has a substantial influence on individual's ethical decisions and moral reasoning ability which is confirmed through empirical studies. However, further research studies in this area is 
highly suggested in the current period due to the immense number of multicultural environment and its influence among individuals compare to the past.

There are conflicting results identified regarding gender over number of studies due to the sample size, geographic differences and the study period. It is recommended that further research need to be perform on gender influences on ethical decision-making by addressing the limitations of prior research. Religious beliefs have been found to have certain level of positive influence on ethical decision-making, however majority of studies conducted in Asia pacific continent. Thus, more studies need to be performed in the western countries and identify whether religion beliefs have any positive influence on ethical decision making or there are other variables drive the ethical decision-making. Finally, there is relationship identified between ethical accounting practices and positive business performance even though they are not enough. Thus, this area can be considered for further research with empirical evidence and diverse sample size.

This research study is exclusively based on secondary data and a small sample size was used for analysis which restricts its ability to confirm significant results. Despite that, this study provided insights on ethics awareness among accounting professionals and how ethical behaviour and practice is core to their profession. The findings of the research can be used as a groundwork for further studies as well. Different variables such as culture, gender and religion influence can be research separately with large sample size and improved research techniques to achieve significant results. This study can be useful for emerging accounting professionals and businesses to obtain a genuine overview to act more ethically in their accounting practices for not only professional growth but also for the greater good of the society.

\section{References}

Abongwa, A. I. (2006). An Empirical Investigation of the Relationship between Culture and Accountants' Attitude towards the Harmonization of International Accounting Standards in United States of America and Cameroon. ProQuest Information and Learning Company, 3197578.

Abuznaid, S. A. (2009). Business ethics in Islam: the glaring gap in practice. International Journal of Islamic and Middle Eastern Finance and Management, 2( 4), 278-288. https://doi.org/10.1108/17538390911006340

Adkins, N., \& Radtke, R. R. (2004). Students' and Faculty Members' Perceptions of the Importance of Business Ethics and Accounting Ethics Education: Is There an Expectations Gap? Journal of Business Ethics, 51, 279-300. 
Anderson, M. E. (2014). National Culture And Differences In Perceptions Of Auditor Independence Under International Codes Of Ethics. ProQuest LLC, 3611394.

Bonawitz, M. F. (2002). Analysis and comparison of the moral development of Florida International University Miami, Florida: UMI Microform 3049799.

Buell, E. K. (2009). The relationship of ethics education to the moral development of accouting students. H. Wayne Huizenga School of Business and Entrepreneurship: UMI Number: 3369513.

Busila, A. B. (2014). Ethical Decision-Making And Religious Identity: A Phenomenological Study On The Impact Of Religious Identity On Ethical Decision-Making In New And Emerging Accounting Professionals. San Francisco, CA: ProQuest LLC, 3642960.

Costuleanu, C. L., Dumitre, D., \& Bobiţan, N. (2013). Creative Accounting During Technological Change. Lucrări Ştiinţifice, 56(2).

Enofe, A. O., Nakpodia, J. O., \& Moruku, J. A. (2014). Ethics and Role of Accountants. European Journal of Business and Management , 6(27), 144-149.

Ghazali, N. A. (2015). The influence of a business ethics course on ethical judgments of Malaysian accountants. Journal of Asia Business Studies, 9(2), 147-157.

Ho, Y.-H. (2009). Associations between the religious beliefs and ethical-reasoning abilities of future accounting professionals. Social Behavior And Personality, 37(5), 673-678. https://doi.org/10.2224/sbp.2009.37.5.673

Hooper, K., \& Xu, G. (2012). From legitimacy by character to legitimacy by image Ethics and accounting practices inNewZealand. Managerial Auditing Journal, 27(8), 754-773. https://doi.org/10.1108/02686901211257037

Holmes, K., Marriott, L., \& Randal, J. (2012). Ethics and experiments in accounting A contribution to the debate on measuring ethical behaviour. Pacific Accounting Review, 24(1), 80-100. https://doi.org/10.1108/01140581211221560

Ibidunni, O. M., Okere, W., Ibidunni, A. \& Joshua, A. (2018). Accounting Ethics And The Performance Of Accounting Firms In Lagos, Nigeria. Journal of Finance and Marketing, 2(2), 10-16. Retrieved from https://www.alliedacademies.org/articles/accounting-ethics-and-the-performance-ofaccounting-firms-in-lagos-nigeria-10470.html https://doi.org/10.35841/financemarketing.2.2.10-16

Isidorsson, G. (2010). Ethics Affecting Business - Improving Ethical Performance. Halmstad University. 
Ismail, S. (2014). Effect of ethical ideologies on ethical judgment of future accountants: Malaysian evidence. Asian Review of Accounting, 22(2), 145-158. https://doi.org/10.1108/ARA-08-2013-0052

Jackling, B., Cooper, B. J., Leung, P., \& Dellaportas, S. (2007). Professional accounting bodies' perceptions of ethical issues, causes of ethical failure and ethics education. Managerial Auditing Journal, 22(9), 928-944.

Jones, H. B., Jr., Furnham, A., \& Deile, A. J. (2010). Religious orientation and the protestant work ethic. Mental Health, Religion and Culture, 13(7-8), 697-706

Joseph, K. O., (2010). Effect of ethical behavior on organizational performance: evidence from three service organizations in Lagos, Nigeria. Journal of Research in National Development, $8(1)$.

Kitchen, S. A. (2006). Gender-Specific Ethical And Behavioral Differences And Employees Who Engage In Accounting Fraud: A Qualitative Case Study. ProQuest Information and Learning Company, 3233720.

Longenecker, J. G., McKinney, J. A., \& Moore, C. (2004). Religious intensity, evangelical Christianity, and business ethics: An empirical study. Journal of Business Ethics, 55, 373386. https://doi.org/10.1007/s10551-004-0990-2

Mirshekary, S., \& Lawrence, A. D. (2009). Academic and Business Ethical Misconduct and Cultural Values: A Cross National Comparison. J Acad Ethics, 7, 141-157.

Mohamed Saat, M., Porter, S. \& Woodbine, G. (2012). A longitudinal study of accounting students' ethical judgment making ability. Accounting Education: An International Journal, 21(3), 215-229.

O’Leary, C., \& Radich, R. (2001). An analysis of Australian final year accountancy students' ethical attitudes. Teaching Business Ethics, 5(3), 235-249.

https://doi.org/10.1023/A:1011482910937

Park, H., \& Blenkinsopp, J. (2013). The impact of ethics programmes and ethical culture on misconduct in public service organizations. International Journal of Public Sector Management, 26(7), 520-533.

Persons, O. (2009). Using a corporate code of ethics to assess students' ethicality: implications for business education. Journal of Education for Business, 84(6), 357-66. https://doi.org/10.3200/JOEB.84.6.357-366

Rahaman, M. M., \& Hossain, M. A. (2014). Ethics in Financial Reporting: A Must. ASA University Review, 8(1). 
Richmond, K. A. (2001). Ethical Reasoning, Machiavellian Behavior, and Gender: The Impact on Accounting Students' Ethical Decision Making. ProQuest Information and Learning Company, 3106790.

Roxas, M. L., \& Stoneback, J. Y. (2004). The Importance of Gender Across Cultures in Ethical Decision-Making. Journal of Business Ethics, 50, 149-165.

https://doi.org/10.1023/B:BUSI.0000022127.51047.ef

Sapp, S. (2015). Financial Reporting, Ethics, The Pressures Accountants Experience And Solutions. ProQuest LLC, 3714851.

Stichter, R. L. (2012). The Effect Of Demographics On The Ethical Sensitivity Of Accounting Students. ProQuest LLC, 3536159.

Stonciuviene, N., \& Naujokaitiene, J. (2013). Formation Of The Ethics Of Professional Accountants From A Moral Standpoint: Analysis Of Decisive Factors And Their Influnce. European Scientific Journal 1.

Su, H.Y. (2014). Business ethics and the development of intellectual capital. Journal of Business Ethics, 119, 87-98. https://doi.org/10.1007/s10551-013-1623-4

Venezia, C. C. (2004). The Ethical Reasoning Abilities Of Accounting Students: Comparison Between The U.S. And Taiwan. ProQuest Information and Learning Company, 3134218. 


\begin{tabular}{|c|c|c|c|c|c|}
\hline Journals & Purpose & Sample & $\begin{array}{c}\text { Instrument / } \\
\text { Test }\end{array}$ & $\begin{array}{l}\text { Findings / } \\
\text { Outcomes }\end{array}$ & Limitations \\
\hline 1 & $\begin{array}{l}\text { Investigate relationship between } \\
\text { claimed behaviour and actual } \\
\text { behaviour, with differences between } \\
\text { males and females and age cohorts }\end{array}$ & $\begin{array}{l}630 \text { undergraduate commerce } \\
\text { students } \\
\text { at a New Zealand University }\end{array}$ & Questionnaires & $\begin{array}{l}\text { Female students } \\
\text { demonstrate more } \\
\text { ethical behaviour then } \\
\text { male }\end{array}$ & $\begin{array}{l}\text { Artificial } \\
\text { representation of } \\
\text { the real world }\end{array}$ \\
\hline 2 & $\begin{array}{l}\text { Significance of gender across } \\
\text { cultures in ethical decision-making }\end{array}$ & $\begin{array}{l}750 \text { students from the US, } \\
\text { Canada, Australia, China, } \\
\text { Philippines and Thailand }\end{array}$ & Ethical Dilemma & Mixed results & $\begin{array}{l}\text { Lack of } \\
\text { generalizability } \\
\text { and small sample } \\
\text { size }\end{array}$ \\
\hline 3 & $\begin{array}{l}\text { Investigate relationship between } \\
\text { culture and accountants' attitude } \\
\text { towards IAS. }\end{array}$ & $\begin{array}{l}\text { Accounting professionals } \\
\text { from multinational and other } \\
\text { business corporations from } \\
\text { Cameroon and the US }\end{array}$ & ANOVA & $\begin{array}{l}\text { Has significant link } \\
\text { between culture and } \\
\text { accountants' attitudes }\end{array}$ & $\begin{array}{l}\text { Limited sample } \\
\text { size of the } \\
\text { countries }\end{array}$ \\
\hline 4 & $\begin{array}{l}\text { Identify how differences in national } \\
\text { cultural impact on the perception of } \\
\text { the auditor independence }\end{array}$ & $\begin{array}{l}\text { Bulgaria as collectivist } \\
\text { country and Belgium as } \\
\text { Individualistic country }\end{array}$ & $\begin{array}{l}\text { Online survey/ } \\
\text { Questionnaires, } \\
\text { ANOVA }\end{array}$ & $\begin{array}{l}\text { Significant differences } \\
\text { do not exists between } \\
\text { auditor independence } \\
\text { and culture and gender }\end{array}$ & $\begin{array}{l}\text { Limited to two } \\
\text { country, no scope } \\
\text { for comparison }\end{array}$ \\
\hline 5 & $\begin{array}{l}\text { Investigate similarities and } \\
\text { differences between academic and }\end{array}$ & $\begin{array}{l}\text { Iranian and Australian } \\
\text { business and commerce }\end{array}$ & Pilot Test & $\begin{array}{l}\text { Gender influence on the } \\
\text { acceptability of }\end{array}$ & $\begin{array}{l}\text { Small sample size } \\
\text { of two countries }\end{array}$ \\
\hline
\end{tabular}


PEOPLE: International Journal of Social Sciences

ISSN 2454-5899

\begin{tabular}{|c|c|c|c|c|c|}
\hline & $\begin{array}{l}\text { business misconduct and cultural } \\
\text { values and gender influence }\end{array}$ & students & & $\begin{array}{l}\text { unethical academic and } \\
\text { business practices }\end{array}$ & $\begin{array}{l}\text { and academic } \\
\text { discipline }\end{array}$ \\
\hline 6 & $\begin{array}{l}\text { Identify if there any differences in } \\
\text { ethical reasoning by culture }\end{array}$ & $\begin{array}{l}\text { Accounting students of } \\
\text { Taiwan and the US }\end{array}$ & $\begin{array}{l}\text { Defining Issue } \\
\text { Test Surveys, } \\
\text { ANOVA }\end{array}$ & $\begin{array}{l}\text { Higher ethical reasoning } \\
\text { among Taiwanese } \\
\text { students then the US }\end{array}$ & $\begin{array}{l}\text { Limited to two } \\
\text { countries }\end{array}$ \\
\hline 7 & $\begin{array}{l}\text { Investigate the accounting students } \\
\text { ethical reasoning process compare to } \\
\text { other business students and influence } \\
\text { of gender }\end{array}$ & $\begin{array}{l}68 \text { Junior and senior } \\
\text { accounting undergraduate } \\
\text { students at a large state } \\
\text { university }\end{array}$ & $\begin{array}{l}\text { Defining Issue } \\
\text { Test, version } 2\end{array}$ & $\begin{array}{l}\text { Female agrees less to } \\
\text { questionable activities } \\
\text { compare to male }\end{array}$ & $\begin{array}{l}\text { Limited to one } \\
\text { University, } \\
\text { surrogate measure } \\
\text { of ethical } \\
\text { reasoning }\end{array}$ \\
\hline 8 & $\begin{array}{l}\text { To determine the relationship } \\
\text { between Culture, Gender, ethical } \\
\text { decision making and fraud }\end{array}$ & $\begin{array}{l}21 \text { companies listed on } \\
\text { Fortune } 500 \text { between } 2001- \\
2002\end{array}$ & Case study & $\begin{array}{l}\text { Female are less likely to } \\
\text { involve in fraudulent } \\
\text { accounting activities }\end{array}$ & $\begin{array}{l}\text { Small number of } \\
\text { companies were } \\
\text { selected as sample }\end{array}$ \\
\hline 9 & $\begin{array}{l}\text { Examining the associations between } \\
\text { ethical decision-making abilities and } \\
\text { religious beliefs }\end{array}$ & $\begin{array}{l}427 \text { Junior and senior } \\
\text { undergraduate accounting } \\
\text { students in Taiwan }\end{array}$ & $\begin{array}{l}\text { Defining Issue } \\
\text { Test, }\end{array}$ & $\begin{array}{l}\text { Students with religious } \\
\text { beliefs tend to present } \\
\text { higher level of ethical- } \\
\text { reasoning abilities }\end{array}$ & $\begin{array}{l}\text { Limited to a } \\
\text { particular country }\end{array}$ \\
\hline 10 & $\begin{array}{l}\text { Effects of demographics on ethical } \\
\text { sensitivity }\end{array}$ & $\begin{array}{l}156 \text { Accounting students } \\
\text { from the Christian Liberal } \\
\text { Universities of the US }\end{array}$ & Survey, ANOVA & $\begin{array}{l}\text { Culture and religion } \\
\text { have an significant } \\
\text { connection with ethical } \\
\text { reasoning }\end{array}$ & $\begin{array}{l}\text { Limited to a } \\
\text { country, ability to } \\
\text { gather data and } \\
\text { small sample size }\end{array}$ \\
\hline
\end{tabular}


PEOPLE: International Journal of Social Sciences

ISSN 2454-5899

\begin{tabular}{|c|c|c|c|c|c|}
\hline 11 & $\begin{array}{l}\text { Impact of religious identity on ethical } \\
\text { decision making in new and } \\
\text { emerging accounting professionals }\end{array}$ & $\begin{array}{l}8 \text { accounting professionals } \\
\text { with } 2 \text {-year experience and } \\
\text { students in the US }\end{array}$ & $\begin{array}{l}\text { In-depth } \\
\text { Interview }\end{array}$ & $\begin{array}{l}\text { Belonging to a group is } \\
\text { more motivating factor } \\
\text { to then the religious } \\
\text { beliefs }\end{array}$ & $\begin{array}{l}\text { Narrow sample } \\
\text { size and limited to } \\
\text { only two } \\
\text { universities }\end{array}$ \\
\hline 12 & $\begin{array}{l}\text { Identify the fraudulent activities in } \\
\text { the accounting related roles, focusing } \\
\text { on situational driven and contextual } \\
\text { elements }\end{array}$ & $\begin{array}{l}192 \text { accounting fraud cases in } \\
\text { Australia during the period of } \\
2001-2011\end{array}$ & $\begin{array}{l}\text { Court cases, } \\
\text { quantitative } \\
\text { analysis }\end{array}$ & $\begin{array}{l}\text { Majority accountant's } \\
\text { fraud has been driven by } \\
\text { situational factors }\end{array}$ & $\begin{array}{l}\text { Limited to a } \\
\text { country }\end{array}$ \\
\hline 13 & $\begin{array}{l}\text { Accountants role in complying with } \\
\text { ethics of the accounting profession }\end{array}$ & $\begin{array}{l}500 \text { random sample was } \\
\text { chosen }\end{array}$ & Questionnaire & $\begin{array}{l}\text { Accountants ethical } \\
\text { behaviours determined } \\
\text { by code of ethics, } \\
\text { policies etc }\end{array}$ & $\begin{array}{l}\text { Random sample } \\
\text { size might not } \\
\text { reflect on the } \\
\text { population }\end{array}$ \\
\hline 14 & $\begin{array}{l}\text { Identify how ethical practices } \\
\text { contribute to organisational ethical } \\
\text { performance }\end{array}$ & $\begin{array}{l}\text { A Swedish company over a } \\
45 \text { billion turnover with } \\
50,000 \text { employees }\end{array}$ & $\begin{array}{l}\text { Questionnaire, } \\
\text { Ethical } \\
\text { Performance } \\
\text { Evaluation } \\
\text { Model }\end{array}$ & $\begin{array}{l}\text { Small steps towards } \\
\text { ethical improvement can } \\
\text { lead organisational } \\
\text { towards ethical } \\
\text { performance. }\end{array}$ & $\begin{array}{l}\text { Uncertain results } \\
\text { due to complexity } \\
\text { to measure ethical } \\
\text { behaviours }\end{array}$ \\
\hline 15 & $\begin{array}{l}\text { Impact of unethical behaviour on } \\
\text { accounting practices }\end{array}$ & $\begin{array}{l}90 \text { graduate accounting } \\
\text { students in Pakistan, aged } \\
\text { between } 19-26 \text { years }\end{array}$ & Survey & $\begin{array}{l}\text { Personal values and } \\
\text { beliefs effect on ethics } \\
\text { and ethical education } \\
\text { can impact on }\end{array}$ & $\begin{array}{l}\text { Limited to } \\
\text { particular country } \\
\text { and small number } \\
\text { of sample size }\end{array}$ \\
\hline
\end{tabular}


PEOPLE: International Journal of Social Sciences

ISSN 2454-5899

\begin{tabular}{|c|c|c|c|c|c|}
\hline & & & & behaviours & \\
\hline 16 & $\begin{array}{l}\text { Effect of national cultural and gender } \\
\text { on ethical decision-making process }\end{array}$ & $\begin{array}{l}24 \text { Latin American } \\
\text { universities final year } \\
\text { accounting students selected } \\
\text { from } 10 \text { countries and the US } \\
\text { has been used as benchmark }\end{array}$ & Survey & $\begin{array}{l}\text { Strong evidence } \\
\text { between culture and } \\
\text { ethics, and partially } \\
\text { support the influence of } \\
\text { gender }\end{array}$ & $\begin{array}{l}\text { Research } \\
\text { conducted among } \\
\text { students who lack } \\
\text { the company or } \\
\text { industry factors }\end{array}$ \\
\hline
\end{tabular}

